\title{
Electrochemical studies on the corrosion of brass in seawater under anaerobic conditions
}

\author{
M. C. Bastos • L. F. A. Proença • M. M. M. Neto • \\ I. T. E. Fonseca
}

Received: 27 February 2007 / Revised: 18 April 2007 / Accepted: 29 May 2007 / Published online: 19 July 2007

(C) Springer-Verlag 2007

\begin{abstract}
This paper reports an electrochemical study on the corrosion of brass in deoxygenated nonbuffered and buffered natural and artificial seawater solutions under anaerobic conditions. Cyclic voltammograms of brass and copper in natural seawater (NSW) and artificial seawater (ASW) were obtained in the passive and transpassive potential regions. The corrosion resistance of brass in natural and artificial seawater was evaluated, and opencircuit potentials were recorded over exposure period of 1 week. Brass samples from 3-month exposures in deoxygenated nonbuffered ASW and NSW, under opencircuit potential, have been imaged by scanning electron microscopy, and the elemental composition of the corrosion products was obtained by energy dispersive spectrometry analysis. It has been concluded that, under anaerobic conditions, the aggressivity of NSW is higher, with brass being less resistant to corrosion than copper, and that buffer contributes to reduce the aggressivity of both media.
\end{abstract}

M. C. Bastos • L. F. A. Proença • M. M. M. Neto •

I. T. E. Fonseca $(\bowtie)$

Departamento de Química e Bioquímica,

Faculdade de Ciências CCMM, Universidade de Lisboa,

Campo Grande, Ed. C8,

1749-016 Lisboa, Portugal

e-mail: itfonseca@fc.ul.pt

M. M. M. Neto

Departamento de Química Agrícola e Ambiental,

Instituto Superior de Agronomia,

Tapada da Ajuda, TULisbon,

1349-017 Lisboa, Portugal

\section{F. A. Proença}

Instituto Superior de Ciências da Saúde Egas Moniz,

Campus Universitário,

Quinta da Granja - Monte de Caparica,

2829-511 Caparica, Portugal
Keywords Brass corrosion · Natural seawater. Synthetic seawater . Anaerobic conditions .

Cyclic voltammetry

\section{Introduction}

Brass is an alloy $(\mathrm{Cu}-\mathrm{Zn})$ commonly used for decoration purposes and also in heating exchanging systems, e.g., desalination and power generation plants $[1,2]$. The corrosion behavior of brass has been extensively studied in a wide range of experimental conditions, with specific interest in the dezincification [3-5], passivation, and pitting corrosion [6-20].

Studies on the corrosion of brass related with dezincification support the conclusion that selective dissolution of zinc and simultaneous dissolution of copper and zinc, followed by the redeposition of copper, take place, alternatively with time, during dezincification. Some works have concluded [3-5] that the removal of zinc leaves behind a porous layer. In nonbuffered neutral or slightly alkaline media, the formation of zinc hydroxide or oxides may occur, leading to local acidification, i.e.:

$\mathrm{Zn} \leftrightarrow \mathrm{Zn}^{2+}+2 \mathrm{e}^{-}$

$\mathrm{Zn}^{2+}+2 \mathrm{H}_{2} \mathrm{O} \leftrightarrow \mathrm{Zn}(\mathrm{OH})_{2}+2 \mathrm{H}^{+}$

and

$\mathrm{Zn}+2 \mathrm{OH}^{-} \leftrightarrow \mathrm{ZnO}+\mathrm{H}_{2} \mathrm{O}+2 \mathrm{e}^{-}$

In chloride media, other reactions involving chloride ions, namely, the formation of chloro-complex compounds, may occur. 
Kabasakaloglu et al. [11] have concluded that the corrosion process of brass in $\mathrm{HCl}$ media starts at $-1.0 \mathrm{~V}$ vs SCE, with the subsequent formation of $\mathrm{ZnO} / \mathrm{Zn}(\mathrm{OH})_{2}$ and zinc ions. According to the authors, dissolution of copper is prevented up to the $\mathrm{CuCl}$ formation potential. Peaks observed at very negative potentials, i.e., around $-1.3 \mathrm{~V}$, have been attributed to the formation of $\mathrm{ZnO} / \mathrm{Zn}$ $(\mathrm{OH})_{2}$. However, this peak at very negative potentials has not been much studied yet.

Morales et al. [8,9], among others, have demonstrated that the dissolution of zinc takes place with anodic polarization even in the passive region. Actually, they showed that the passive layer formed on $\mathrm{Cu}-\mathrm{Zn}$ alloys in chloride-buffered media consists of a film whose composition is $\mathrm{ZnO} \cdot \mathrm{xH}_{2} \mathrm{O}+\mathrm{Cu}_{2} \mathrm{O}+\mathrm{CuO} / \mathrm{Cu}(\mathrm{OH})_{2}+\mathrm{CuCl}[17-$ $19,28]$. During the anodic polarization, the dissolution of the passive film occurs above a certain potential, known as the breakdown potential, $E_{\mathrm{b}}$, which shifts negatively as the chloride concentration increases. Those authors have concluded that brass is less resistant to corrosion than copper. The breakdown of the passivity has been attributed to the formation of soluble species, i.e., chloro- and/or oxycomplexes, e.g.:

$$
\begin{aligned}
& \mathrm{Cu}+\mathrm{Cl}^{-} \leftrightarrow \mathrm{CuCl}^{-} \\
& \mathrm{CuCl}+\mathrm{Cl}^{-} \leftrightarrow \mathrm{CuCl}_{2}^{-} \\
& 2 \mathrm{CuCl}_{2}^{-}+\mathrm{Zn} \leftrightarrow 2 \mathrm{Cu}+\mathrm{ZnCl}_{4}^{2-} \\
& \mathrm{CuO}+\mathrm{Zn}+4 \mathrm{Cl}^{-}+\mathrm{H}_{2} \mathrm{O} \leftrightarrow \mathrm{Cu}+\mathrm{ZnCl}_{4}^{2-}+2 \mathrm{OH}^{-} \\
& \mathrm{Cu}(\mathrm{OH})_{2}+\mathrm{Zn}+2 \mathrm{Cl}^{-} \leftrightarrow \mathrm{Cu}+\mathrm{Zn}(\mathrm{OH})_{2} \mathrm{Cl}_{2}^{2-} \\
& \mathrm{Zn}(\mathrm{OH})_{2} \leftrightarrow \mathrm{HZnO}_{2}^{-}+\mathrm{H}^{+} \\
& \mathrm{HZnO}_{2}^{-} \leftrightarrow \mathrm{ZnO}_{2}^{2-}+\mathrm{H}^{+}
\end{aligned}
$$

Brass corrosion in seawater has been studied by several authors [21-27]. The literature reports studies on the influence of the composition of the alloy [12], chloride concentration, presence of other aggressive anions, e.g., I', $\mathrm{F}^{-}, \mathrm{Br}^{-}$, and $\mathrm{SO}_{4}^{2-}$, as well as temperature [9], $\mathrm{pH}$, illumination [13], and the presence of microorganisms [21] on the resistance of brass to aggressive media. Studies related with the inhibition of the corrosion of brass have also been reported by Sinapi et al. [28, 29] and by Mountassir and Srhiri [30], among others.

In the present paper, a comparative study is performed on the voltammetric behavior of brass in natural and artificial seawater under similar experimental conditions. In spite of the large amount of data which can be found in the literature, no work seems to have been previously published on this purpose. Our prior articles on the corrosion of brass $[24,25]$ have suggested that it would be also important to consider the corrosion under anaerobic conditions; which is now taken into account. On the other hand, because seawater is an excellent buffer system, due to the interactions of $\mathrm{CO}_{2}$ with $\mathrm{H}_{2} \mathrm{O}(\mathrm{pH}$ 7.5-8.5), we decided to pursue this study with a buffered artificial seawater solution $(\mathrm{pH}=9.0)$.

\section{Materials and methods}

The brass used in this study has the following chemical composition ( $w / w \%): 63.8 \% \mathrm{Cu}+36 \% \mathrm{Zn}+0.007 \% \mathrm{Sn}+$ $0.08 \% \mathrm{~Pb}+0.09 \% \mathrm{Ni}+0.018 \% \mathrm{Fe}+0.001 \% \mathrm{Al}$. The working electrodes were obtained by cutting discs from a commercial brass rod purchased from Goodfellows. A three-electrode two-compartment cell was used for the electrochemical studies. The secondary electrode was a platinum foil, and the reference electrode was a commercial silver/silver chloride electrode $(\mathrm{Ag} \mid \mathrm{AgCl}, \mathrm{KCl} 3 \mathrm{M})$ connected to the main compartment of the cell by a Luggin capillary.

The working electrode (area: $0.196 \mathrm{~cm}^{2}$ ) was mechanically polished with alumina powder down to $0.05 \mu \mathrm{m}$, then was rinsed several times with distilled water, and finally was dried with acetone. Before each voltammetric experiment, the brass electrode was polarized for $15 \mathrm{~s}$ at $-1.4 \mathrm{~V}$

Table 1 Composition of the ASW and NSW solutions

\begin{tabular}{lllllllllllll}
\hline Media & \multicolumn{1}{l}{ Concentration $\left(\mathrm{g} \mathrm{dm}^{-3}\right)$} \\
\cline { 2 - 10 } & $\mathrm{Cl}^{-}$ & $\mathrm{SO}_{4}^{2-}$ & $\mathrm{CO}_{3}^{2-} / \mathrm{HCO}_{3}^{-}$ & $\mathrm{Na}^{+}$ & $\mathrm{Mg}^{2+}$ & $\mathrm{K}^{+}$ & $\mathrm{Ca}^{2+}$ & $\mathrm{Sr}^{2+}$ & $\mathrm{NO}_{3}^{-}$ & $\mathrm{Br}^{-}$ & $\mathrm{I}^{-}$ & $\mathrm{F}^{-}$ \\
\hline $\mathrm{ASW}$ & 19.3 & 2.66 & 0.20 & 10.7 & 1.32 & 0.42 & 0.40 & $9 \times 10^{-3}$ & - & $<5 \times 10^{-3}$ & $2 \times 10^{-4}$ & $1 \times 10^{-3}$ \\
$\mathrm{NSW}$ & 20.0 & 2.90 & 0.18 & 11.0 & 1.32 & 0.40 & 0.56 & - & $2 \times 10^{-3}$ & $\leq 0.5 \times 10^{-3}$ & \\
\hline
\end{tabular}


Table 2 Chemical physical properties of the ASW and NSW

\begin{tabular}{lllll}
\hline Medium & Color & Smell & $\mathrm{pH}_{20}{ }^{\circ} \mathrm{C}$ & $\chi_{20}{ }^{\circ} \mathrm{C} / \mathrm{mS} \mathrm{cm}^{-1}$ \\
\hline ASW & Clear colorless & Odorless & 8.9 & 42.0 \\
NSW & Clear colorless & Odorless & 8.1 & 44.6 \\
\hline
\end{tabular}

vs $\mathrm{Ag} \mid \mathrm{AgCl}$. Dissolved $\mathrm{O}_{2}$ was removed by bubbling $\mathrm{N}_{2}$ (L' Air Liquid).

A solution of synthetic seawater ( $3 \%$ in sea salts from Sigma), resembling the composition of the dissolved salts of ocean seawater, was prepared using deionized Milli-Q water from Millipore. The synthetic seawater, from Sigma Aldrich, was composed by the following inorganic compounds: $\mathrm{NaCl}, \mathrm{Na}_{2} \mathrm{SO}_{4}, \mathrm{MgCl}_{2} \cdot 6 \mathrm{H}_{2} \mathrm{O}, \mathrm{CaCl}_{2} \cdot 2 \mathrm{H}_{2} \mathrm{O}, \mathrm{KCl}$, $\mathrm{SrCl}_{2} \cdot 6 \mathrm{H}_{2} \mathrm{O}, \mathrm{NaHCO}_{3}, \mathrm{KBr}$, and $\mathrm{H}_{3} \mathrm{BO}_{3}$ plus minor amounts of $\mathrm{I}^{-}, \mathrm{F}^{-}$, and $\mathrm{Li}^{+}$.

Natural seawater (NSW) was collected at Ericeira Beach, on the western coast of Portugal, in February 2006 (winter time), transported and kept in the laboratory at $4{ }^{\circ} \mathrm{C}$. The chemical analysis of the NSW samples was carried out according to standard methods [31], leading to the concentrations given in Tables 1 and 2.

The chemical physical properties of both solutions are expressed in Table 2.

The $\mathrm{pH}$ of both solutions was adjusted to 9.0 with borax buffer $\left(0.025 \mathrm{M} \mathrm{Na}_{2} \mathrm{~B}_{4} \mathrm{O}_{7}+0.05 \mathrm{M} \mathrm{H}_{3} \mathrm{BO}_{3}\right)$.

It should be pointed out that ASW (Sigma Aldrich) contains only inorganic compounds, whereas NSW contains, among other components, also organic compounds, small amounts of nitrites and nitrates, trace elements, and eventually extracellular exopolymers (EPS) from the bacterial activity under anaerobic conditions. The levels of oxygen could also bring differences in the aggressivity of both samples, but the experiments were performed under anaerobic conditions, therefore the influence of the levels of oxygen does not have to be considered. The $\mathrm{pH}$ does not either because both solutions were buffered $(\mathrm{pH}=9.0)$.

Cyclic voltammetric studies were performed via a modular automated acquisition system Autolab (Eco Chemie, Utrecht, The Netherlands) composed by a Potentiostat PSAST 10, a digital/analogic converter, DAC 124, connected to a personal computer equipped with GPES software (version 4.7).

The open-circuit potentials (OCPs) of brass samples immersed in natural and in artificial seawater were acquired with a digital $\mathrm{HP}^{\circledR} 34$ 401A multimeter connected through an RS-232 interface to an IBM PC model 80286, which allowed automatic data acquisition.

SEM studies were performed using a scanning electron microscope JEOL JSM 35 C Noran. The EDS spectra were recorded with an X-ray diffractometer.

\section{Results and discussion}

Cyclic voltammetric studies

\section{General voltammetric profiles of brass in buffered ASW}

Figure 1 gives cyclic voltammograms of brass in deoxygenated buffered ASW, at various reversing anodic potentials, $E_{\lambda \mathrm{a}}$, in the passive and in the transpassive regions. Only a few studies report the cathodic peak, which appears at very negative potentials, i.e., at potentials between -1.2 and $-1.3 \mathrm{~V}$ vs $\mathrm{Ag} \mid \mathrm{AgCl}$. This peak has deserved our attention.

CVs of Fig. 1 present a pattern quite similar to those reported in the literature for brass in neutral and basic aqueous solutions $[8,11-13,16,17,28]$. The presence of $\mathrm{Zn}$ in the alloy contributes to the appearance of a welldefined reduction peak, $C_{\mathrm{IV}}$, observed during the reverse scan, with a peak potential of $-1.2 \mathrm{~V}$, as the polarization potential advances in the anodic direction. This cathodic peak can be attributed to the reduction of the $\mathrm{ZnO} / \mathrm{Zn}(\mathrm{OH})_{2}$ formed at peak $A_{\mathrm{IV}}$ (Fig. 1a), located at about $-1.1 \mathrm{~V}$, and/ or related with the reduction of soluble zinc species, e.g., $\mathrm{Zn}^{2+}, \mathrm{ZnO}_{2}^{2-}$, or $\mathrm{Cl}_{4} \mathrm{Zn}^{2-}$. It should be remarked that this cathodic peak, at very negative potentials, keeps its shape and suffers only a slight increase, as the polarization potential advances to $+0.05 \mathrm{~V}$ vs $\mathrm{Ag} \mid \mathrm{AgCl}$. Then, when the transpassive region is reached, i.e., for $E_{\lambda \mathrm{a}}>+0.1 \mathrm{~V}$, it disappears (see Fig. 1b). On the other hand, during the anodic scan from -1.0 to $-0.1 \mathrm{~V}$, other oxidation processes related with copper oxidation take place, at small extent, yielding peak $C_{\mathrm{III}}$ at $-0.97 \mathrm{~V}$ (Fig. 1a) during the reverse scan. This peak has been attributed to the reduction of the $\mathrm{Cu}(\mathrm{I})$ oxide species.

For $E_{\lambda \mathrm{a}}$ ranging between -0.05 and $+0.05 \mathrm{~V}$, a third cathodic peak, $C_{\mathrm{II}}$, starts to appear at $-0.35 \mathrm{~V}$ (see Fig. 1a). This peak is necessarily related with the oxidation processes during the corresponding anodic scan, and according to the literature [6, 8, 17-19], the most expected species formed, under such conditions, are the $\mathrm{Cu}$ (II) oxides, $\mathrm{CuO}$ / $\mathrm{Cu}(\mathrm{OH})_{2}$, and/or $\mathrm{Cu}(\mathrm{II})$ chloride species. When $E_{\lambda \mathrm{a}}$ reaches the value $+0.1 \mathrm{~V}$, a substantial increase of the anodic current is observed (see Fig. 1b), with a significant increase of the charge associated to peak $C_{\mathrm{I}}$. A critical region corresponding to the destruction of the passivity and the 
occurrence of pitting corrosion has been reached because the reverse scan shows a current loop related with the nucleation and growth of pits. During the reverse scan, a crossover of the two curves is observed at a potential called the repassivation or protection potential, $E_{\text {repass. }}$ During the anodic scan, the oxidation process in the transpassive region leads to the formation of $\mathrm{Cu}^{2+}$ and other soluble complex species, e.g., $\mathrm{Cu}(\mathrm{II})$ chloride complexes. Peak $C_{\mathrm{I}}$ testifies their reduction. The corresponding cathodic charges suffer a significant increase owing to the destruction of passivity and the consequent occurrence of pitting. A considerable increase in charge is observed for polarizations between +0.2 and $+0.3 \mathrm{~V}$. Pits formed under the conditions of Fig. $1 \mathrm{~b}$ were not visible with the naked eye, but they could be seen through a magnifying glass. However, when very low scan rates were used (of the order of $1 \mathrm{mV} \mathrm{s}^{-1}$ ), or the when polarization potential was held for a few minutes at $E>0.1 \mathrm{~V}$, then pits were quite evident.
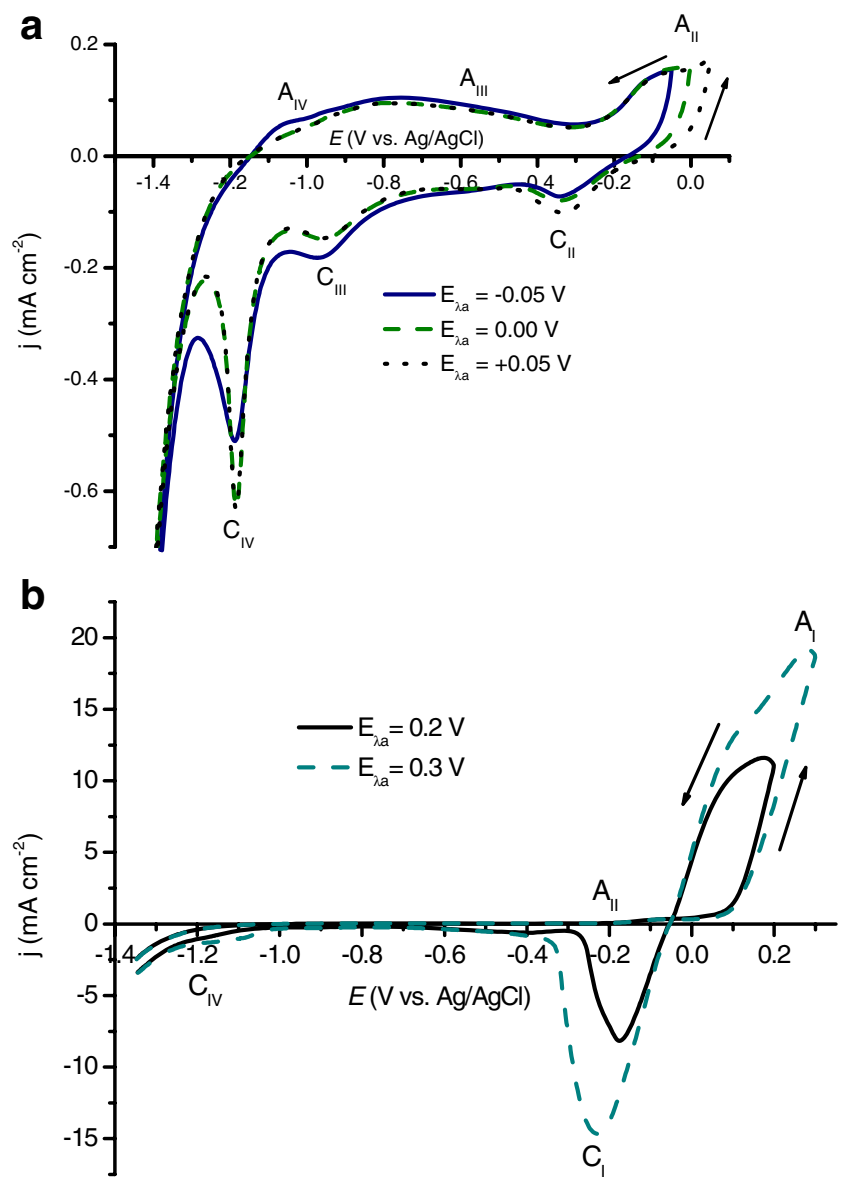

Fig. 1 Cyclic voltammograms of brass in deoxygenated buffered ASW (pH=9.0) at various reversing anodic potentials: a $E_{\lambda \mathrm{a}}:-0.05 \mathrm{~V}$ (solid line), $0.0 \mathrm{~V}$ (dashed line), $+0.05 \mathrm{~V}$ (dotted line). $\mathbf{b} E_{\lambda \mathrm{a}}:=0.2 \mathrm{~V}$ (solid line), $0.30 \mathrm{~V}$ (dashed line). $\nu=50 \mathrm{mV} \mathrm{s}^{-1}$
According to the literature $[7,8,10-12,18]$, peaks $A_{\mathrm{I}} / C_{\mathrm{I}}$, $A_{\mathrm{II}} / C_{\mathrm{II}}, A_{\mathrm{III}} / C_{\mathrm{III}}$ and $A_{\mathrm{IV}} / C_{\mathrm{IV}}$ may be attributed to the following reversible reactions:

$2 \mathrm{Cu}+2 \mathrm{OH}^{-} \leftrightarrow \mathrm{Cu}_{2} \mathrm{O}+\mathrm{H}_{2} \mathrm{O}+2 \mathrm{e}^{-}\left(A_{\mathrm{III}} / C_{\mathrm{III}}\right)$

$\mathrm{Cu}+6 \mathrm{Cl}^{-} \leftrightarrow 3 \mathrm{Cl}_{2} \mathrm{Cu}^{-}+3 \mathrm{e}^{-}\left(A_{\mathrm{III}} / C_{\mathrm{III}}\right)$

$\mathrm{Cu}+2 \mathrm{Cl}^{-} \leftrightarrow \mathrm{CuCl}_{2}^{-}+\mathrm{e}^{-}\left(A_{\mathrm{III}} / C_{\mathrm{III}}\right)$

$\mathrm{Cu}_{2} \mathrm{O}+2 \mathrm{OH}^{-} \leftrightarrow 2 \mathrm{CuO}+\mathrm{H}_{2} \mathrm{O}+2 \mathrm{e}^{-}\left(A_{\mathrm{II}} / C_{\mathrm{II}}\right)$

$\mathrm{Cu}_{2} \mathrm{O}+\mathrm{H}_{2} \mathrm{O}+2 \mathrm{OH}^{-} \leftrightarrow 2 \mathrm{Cu}(\mathrm{OH})_{2}+2 \mathrm{e}^{-}\left(A_{\mathrm{I}} / C_{\mathrm{I}}\right)$

a

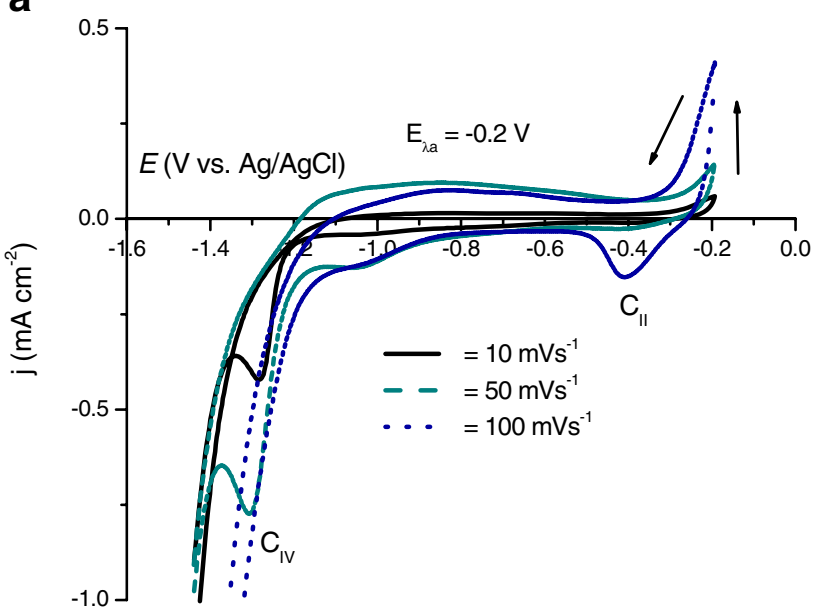

b

Fig. 2 a CVs of brass at three sweep rates. b Cathodic sides of the CVs of brass in deoxygenated buffered ASW, polarized at $E_{\lambda \mathrm{a}}=-0.15 \mathrm{~V}$, during $5 \mathrm{~min}$ (solid line) and $20 \mathrm{~min}$ (dashed line). $\nu=10 \mathrm{mV} \mathrm{s}^{-1} . E_{\mathrm{i}}=-1.5 \mathrm{~V}$ 

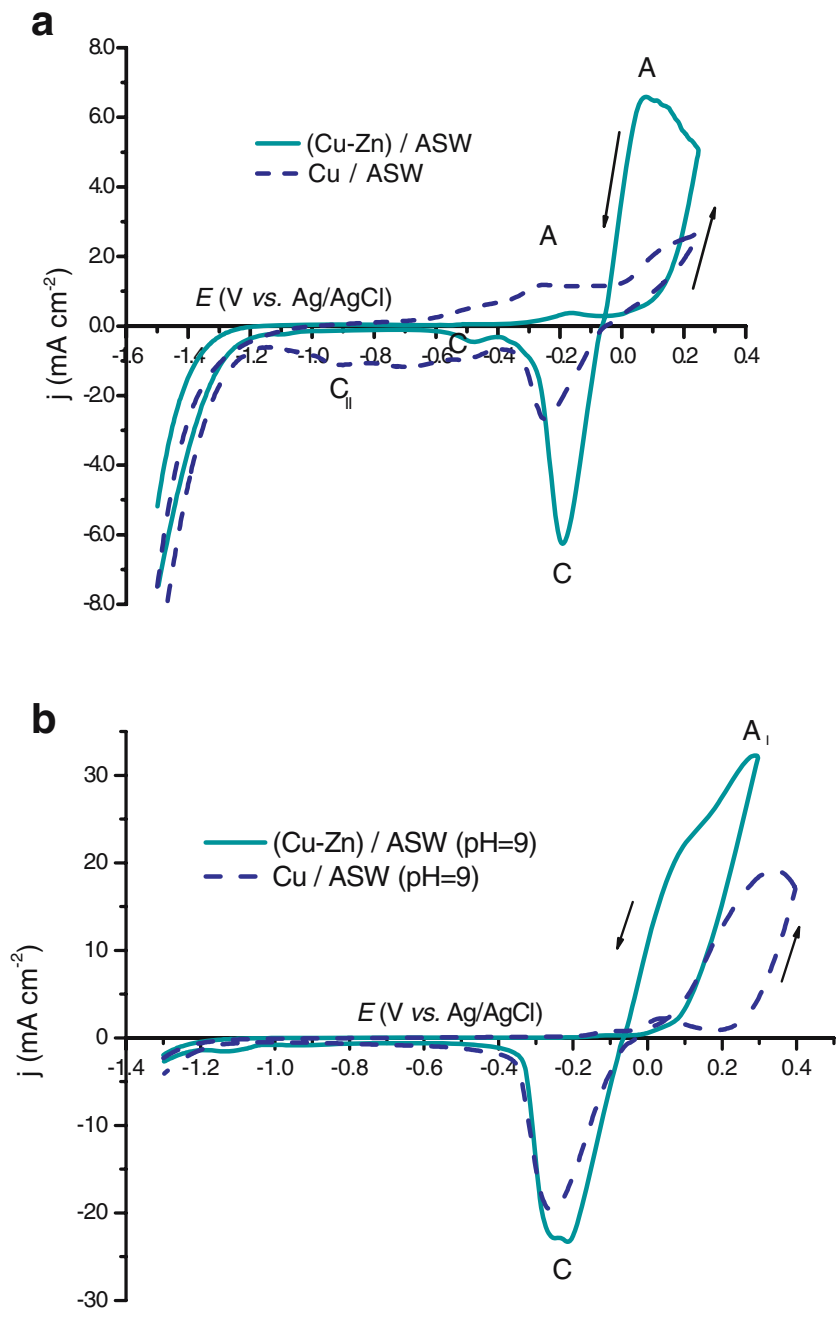

Fig. $3 \mathrm{CVs}$ from brass (solid line) and copper (dashed line) in deoxygenated ASW: a nonbuffered ASW: $E_{\lambda \mathrm{a}}=+0.20 \mathrm{~V}$, b buffered, at $\mathrm{pH}=9.0, E_{\lambda \mathrm{a}}=+0.3 \mathrm{~V}$ (solid line) and $E_{\lambda \mathrm{a}}=+0.4 \mathrm{~V}$ (dashed line). $\nu=50 \mathrm{mV} \mathrm{s}^{-1}$

$\mathrm{Cu} \leftrightarrow \mathrm{Cu}^{2+}+2 \mathrm{e}^{-}\left(A_{\mathrm{I}} / C_{\mathrm{I}}\right)$

$\mathrm{Zn} \leftrightarrow \mathrm{Zn}^{2+}+2 \mathrm{e}^{-}\left(A_{\mathrm{IV}} / C_{\mathrm{IV}}\right)$

$\mathrm{Zn}+2 \mathrm{OH}^{-} \leftrightarrow \mathrm{ZnO}+\mathrm{H}_{2} \mathrm{O}+2 \mathrm{e}^{-}\left(A_{\mathrm{IV}} / C_{\mathrm{IV}}\right)$
$\mathrm{Zn}+2 \mathrm{OH}^{-} \leftrightarrow \mathrm{Zn}(\mathrm{OH})_{2}+2 \mathrm{e}^{-}\left(A_{\mathrm{IV}} / C_{\mathrm{IV}}\right)$

During the pitting of brass in the passive state, the precipitation of $(\mathrm{Cu}-\mathrm{Zn})(\mathrm{OH})_{3} \mathrm{Cl}$ (paratacamite) may take place, depending on the potential and polarization time. In fact, during the pitting of admiralty brass of heat exchangers in seawater, Morales et al. [19] have observed the formation of a green precipitate, which they have identified by X-ray spectroscopy as paratacamite. The formation of paratacamite may be due to chemical reactions involving the chloride complexes, e.g., $\mathrm{Cl}_{4} \mathrm{Zn}^{2-}$ and $\mathrm{ClCu}^{+}$, leading to the formation of $(\mathrm{Cu}-\mathrm{Zn})(\mathrm{OH})_{3} \mathrm{Cl}$, according to the reaction:

$$
\begin{aligned}
& \mathrm{Cl}_{4} \mathrm{Zn}^{2+}+\mathrm{ClCu}^{+}+3 \mathrm{H}_{2} \mathrm{O} \\
& \leftrightarrow(\mathrm{Cu}-\mathrm{Zn})(\mathrm{OH})_{3} \mathrm{Cl}+3 \mathrm{H}^{+}+4 \mathrm{Cl}^{-}
\end{aligned}
$$

The influence of the sweep rate on the definition of peak $C_{\mathrm{IV}}$ is shown in Fig. 2.

Data in Fig. 2 show clearly that peak $C_{\mathrm{IV}}$ is a welldefined peak only at scan rates lower than $0.1 \mathrm{~V} \mathrm{~s}^{-1}$. It is also noticed that peak $C_{\mathrm{IV}}$ increases and is better defined for polarizations lower than $20 \mathrm{~min}$ at $-0.05 \mathrm{~V}$. For longer polarization times, both peaks $A_{\mathrm{II}}$ and $C_{\mathrm{II}}$ develop, whereas peak $C_{\mathrm{IV}}$ decreases.

\section{Cyclic voltammograms of brass vs copper}

Figure 3 shows CVs corresponding to brass and copper electrodes polarized in nonbuffered and buffered deoxygenated ASW.

Table 3 summarizes data from CVs of Fig. 3. It is evident that the breakdown of passivity takes place at much more noble potentials for copper, which means that the passive film presents higher stability. Peak $C_{\mathrm{IV}}$ is observed only on the CVs from brass and not on those from copper. For polarization of $E \leq+0.2 \mathrm{~V}$, the oxidation charges, under the anodic sides of the CVs from brass, are much higher than the corresponding ones for copper, which means that, under identical conditions, brass is less resistant to corrosion than copper.

\begin{tabular}{|c|c|c|c|c|c|c|c|c|c|c|}
\hline \multirow[t]{2}{*}{ ASW solutions } & \multirow[t]{2}{*}{ Samples } & \multicolumn{8}{|c|}{$E\left(\mathrm{~V}\right.$ vs $\left.\mathrm{Ag}_{\mid}^{\prime} \mathrm{AgCl}\right)$} & \multirow{2}{*}{$\begin{array}{l}Q\left(\mathrm{mC} \mathrm{cm}^{-2}\right) \\
Q_{\mathrm{an}}\end{array}$} \\
\hline & & $E_{\lambda \mathrm{a}}$ & $E_{A \mathrm{I}}$ & $E_{C I}$ & $E_{A \mathrm{II}}$ & $E_{C I I}$ & $E_{\mathrm{CIV}}$ & $E_{\mathrm{b}}$ & $E_{\text {repass }}$ & \\
\hline \multirow[t]{2}{*}{ Nonbuffered } & Brass & +0.2 & 0.10 & -0.17 & -0.18 & -0.48 & - & 0.079 & -0.063 & 22.5 \\
\hline & Copper & +0.2 & - & -0.25 & -0.28 & -0.70 & - & 0.27 & +0.053 & 12.5 \\
\hline \multirow[t]{2}{*}{ Buffered, $\mathrm{pH}=9.0$} & Brass & +0.3 & 0.10 & -0.22 & - & - & -1.1 & 0.14 & -0.058 & 75.6 \\
\hline & Copper & +0.4 & 0.32 & -0.28 & - & - & - & +0.28 & +0.15 & 63.4 \\
\hline
\end{tabular}

Table 3 Data from CVs of brass and copper in nonbuffered and buffered deoxygenated ASW 
Fig. 4 CVs from brass in deoxygenated buffered ASW (solid line) and NSW (dashed line). a $E_{\lambda \mathrm{a}}=0 \mathrm{~V} ; \mathbf{b} E_{\lambda \mathrm{a}}=+0.3 \mathrm{~V}$ vs $\mathrm{Ag} \mid \mathrm{AgCl} . \nu=50 \mathrm{mV} \mathrm{s}^{-1}$
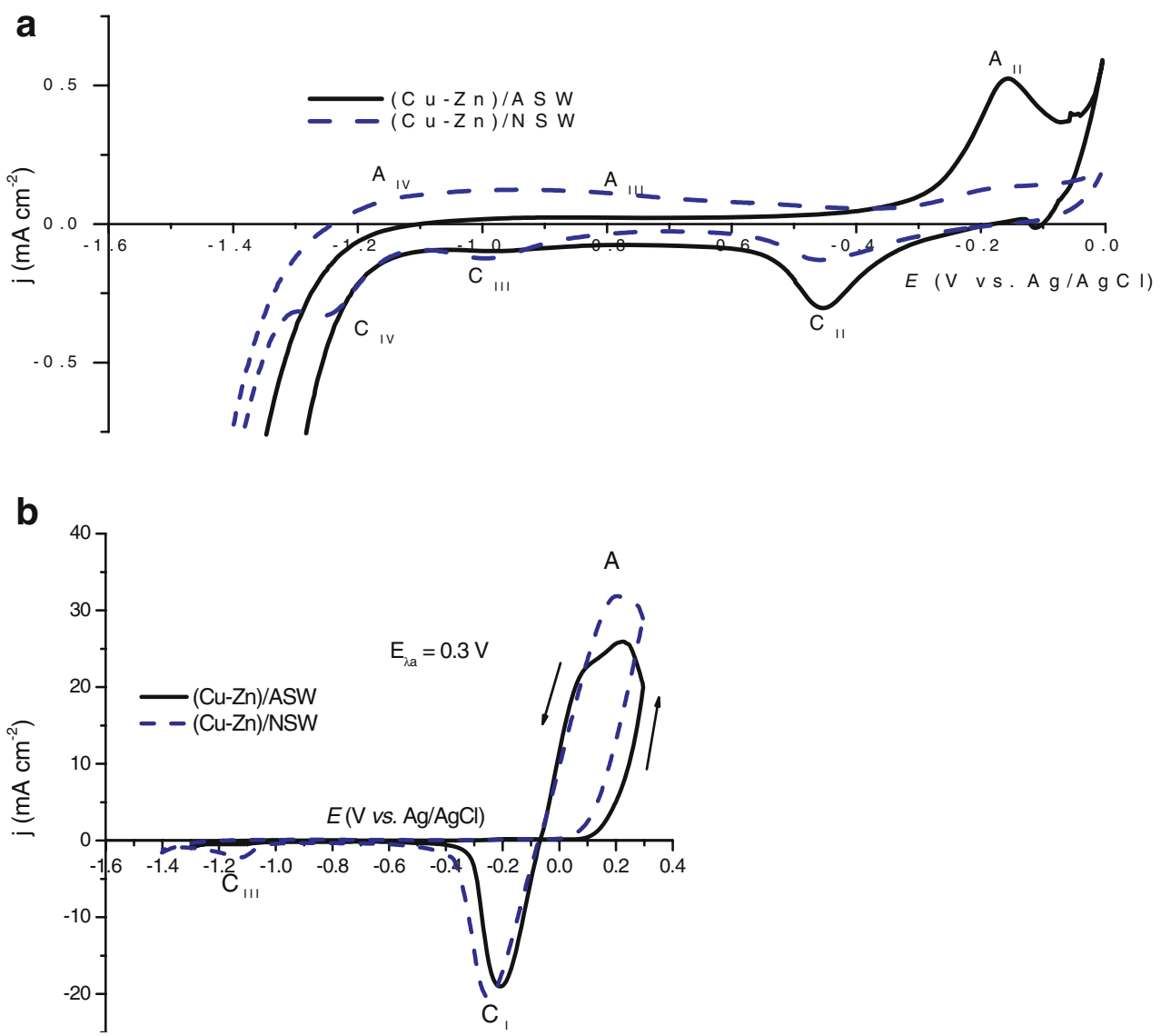

CVs of brass in buffered NSW vs ASW

Figure 4 presents the CVs of brass in deoxygenated buffered natural and artificial seawater.

As shown in Fig. 4, for polarizations in the passive region, the CVs of brass, in both media, exhibit quite different patterns. In ASW, a well-defined pair of peaks $\left(A_{\mathrm{II}} / C_{\mathrm{II}}\right)$ is presented, as well as higher anodic and cathodic charges. For polarizations reaching the transpassive region, the CVs, corresponding to both media, are quite similar. In this case, the oxidation charges are only slightly higher on the CVs of brass in NSW (see also data in Table 4).

Once more, data show that the breakdown potential of passivity is less noble in NSW and that the peaks $C_{\mathrm{III}}$ and $C_{\mathrm{IV}}$ in spite of being small are better defined on the CVs of brass in NSW, which means that the NSW favors the formation of zinc species reducible during the next cathodic cycle.

For higher values of polarizations, i.e., $E_{\lambda \mathrm{a}}=0.3 \mathrm{~V}$, all the anodic peaks are shifted to less anodic values and the breakdown of passivity takes place also at much less noble potentials for brass in NSW.

\section{Polarization curves: Tafel analysis}

Figure 5 presents polarization curves, in their logarithmic form, of brass in buffered NSW and ASW, recorded at $1 \mathrm{mV} \mathrm{s}^{-1}$.

Figure 6 depicts the straight lines corresponding to potential values of $E_{\mathrm{corr}} \pm 20 \mathrm{mV}$ (LPR) for the evaluation of

Table 4 Electrochemical data from brass polarized in natural and artificial seawater solutions

\begin{tabular}{|c|c|c|c|c|c|c|c|c|c|c|}
\hline \multirow[t]{2}{*}{$E_{\lambda a} / V$} & \multirow[t]{2}{*}{ Medium } & \multicolumn{8}{|c|}{$E\left(\mathrm{~V}\right.$ vs $\left.\mathrm{Ag}_{\mid}^{\prime} \mathrm{AgCl}\right)$} & \multirow{2}{*}{$\begin{array}{l}\left.Q(\mathrm{mC} \mathrm{cm})^{-2}\right) \\
Q_{\mathrm{an}}\end{array}$} \\
\hline & & $A_{\mathrm{I}}$ & $C_{\mathrm{I}}$ & $A_{\mathrm{II}}$ & $C_{\mathrm{II}}$ & $C_{\mathrm{III}}$ & $C_{\mathrm{IV}}$ & $E_{\mathrm{b}}$ & $E_{\text {pass }}$ & \\
\hline \multirow[t]{2}{*}{0.0} & ASW & - & - & -0.20 & -0.45 & - & - & - & - & 2.97 \\
\hline & NSW & - & - & - & -0.45 & -0.99 & -1.25 & - & - & 1.98 \\
\hline \multirow[t]{2}{*}{0.30} & ASW & 0.19 & -0.22 & - & - & - & - & 0.14 & -0.070 & 89.0 \\
\hline & NSW & 0.18 & -0.28 & - & - & -1.1 & -1.25 & 0.076 & -0.071 & 100.6 \\
\hline
\end{tabular}




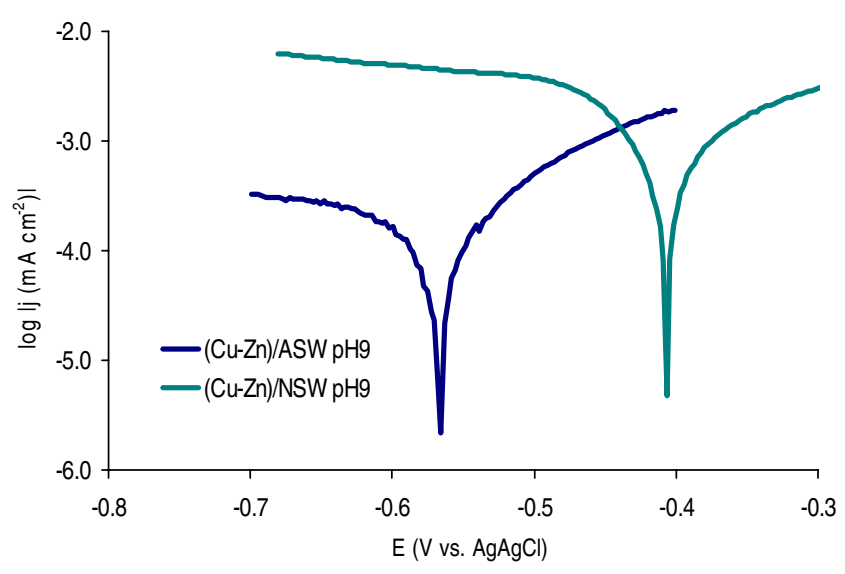

Fig. 5 Logarithmic plots of the polarization curves of brass in buffered NSW (solid line) and ASW (solid line)

the polarization resistance, $R_{\mathrm{p}}$; for the two systems considered in this study.

Values of the polarization resistance, $R_{\mathrm{p}}$, obtained by the linear polarization method (LPR), are given in Table 5. The Tafel analysis of the polarization curves has also been performed, and the obtained corrosion data are presented.

Considering the corrosion current densities given in Table 5, it is clear that NSW is more aggressive than ASW. On the other hand, in terms of the corrosion potential, brass samples immersed in ASW present a less noble potential (more negative). Thus, in thermodynamic terms, ASW is more aggressive for brass corrosion than NSW.

The higher aggressivity of NSW, in comparison with that of ASW, is necessarily due to the differences in the composition of both solutions already mentioned in the experimental section, most probably related either with organic compounds and/or with the EPS produced by the bacterian activity because under anaerobic conditions, microbiologically influenced corrosion may take place. To confirm this hypothesis, it could be important to perform experiments by adding organic compounds to the ASW solution and/or by reducing the microbial activity. This could be achieved by performing experiments under sterilized conditions or even by working under controlled bacterial activity.

\section{Open-circuit potential curves}

Figure 7 gives the OCP curves of brass in nondeoxygenated buffered NSW and ASW.

Although the easiest electrochemical test for corrosion studies is based on measurements of the open-circuit potentials (OCPs), it is well known that it provides the least amount of mechanistic information. However, many corrosion studies have used measurements of the OCPs.

According to Mansfeld et al. [32], the sustainable noble potentials (more positive values) mean that the metal or alloy retains its normal corrosion resistance, whereas, if localized corrosion has occurred, the OCP drops to the active potentials typical of localized corrosion. The experimental results show much less noble values of the OCP in NSW, in agreement with the previous conclusions. In both media, during the first days of immersion, the OCP is displaced to the positive direction, reaching a maximum during the first
Fig. 6 Straight lines for the evaluation of $R_{\mathrm{p}}$ of the two systems indicated on the inset

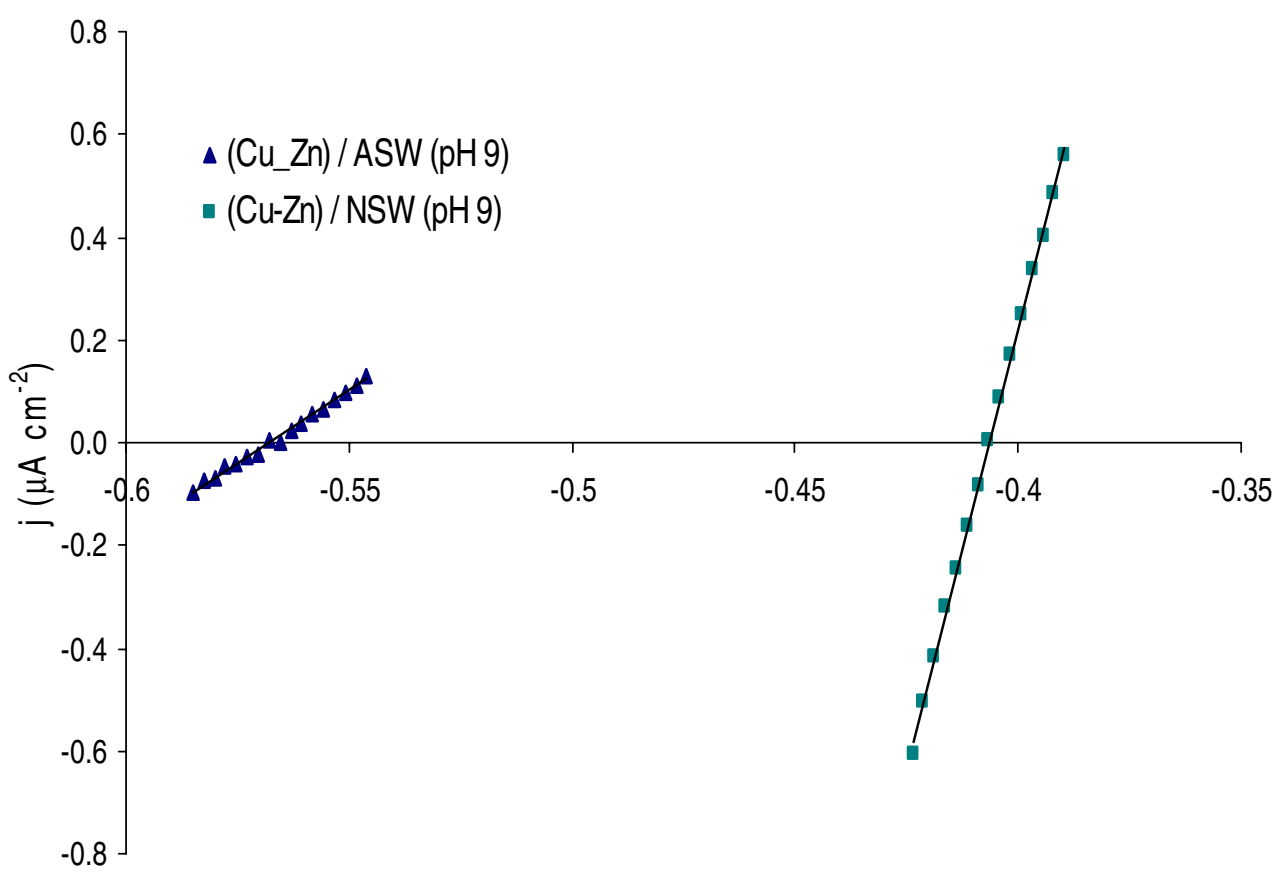

$E(\mathrm{Vvs.} \mathrm{Ag/AgCl})$ 
2 days in NSW and after only 5 days in ASW. Then, it changes to less positive values presenting slight oscillations of smaller amplitude when the sample is in NSW. OCP data show again that NSW behaves as a more aggressive medium.

\section{SEM images and EDS spectra}

The morphology of the surfaces of brass samples from immersions in ASW, before the removal of the corrosion products, shows large white zones for which $\mathrm{Cu}$ and $\mathrm{Zn}$ were the main elements identified by EDS, most probably zones where dezincification takes place. Zone Z2 corresponds to cracked areas which present big amounts of corrosion products at the bottom of cracks. The polygonal precipitates are mainly composed of $\mathrm{Cl}$ and $\mathrm{Na}$, so most probably, they are crystals of $\mathrm{NaCl}$. Zone $\mathrm{Z3}$ covering the whole surface presents, apart from $\mathrm{Cu}$ and $\mathrm{Zn}, \mathrm{Cl}$ and $\mathrm{S}$ in quite high percentages and $\mathrm{O}$ in lower percentages. Thus, copper and zinc chlorides and sulfates and also oxides may be the corrosion products covering the whole surface.

Images of brass samples exposed to NSW show corrosion products covering the surface in which the EDS identifies, apart from $\mathrm{Zn}$ and $\mathrm{Cu}$, also $\mathrm{Cl}$, in a high percentage and in a smaller percentage of $\mathrm{O}$. Thus, most probably, these corrosion products are zinc and copper chlorides and oxides. Zone Z2 presents the polygonal and large precipitates distributed all over the surface mainly composed of $\mathrm{Na}$ and $\mathrm{Cl}$ with a shape characteristic of $\mathrm{NaCl}$ crystals.

Finally, zone Z3 exhibits round and small precipitates uniformly distributed over the whole surface. The EDS identifies high percentages of $\mathrm{S}$ and only very small percentages of $\mathrm{O}$ and $\mathrm{Cl}$ plus high percentages of $\mathrm{Na}$. Hence, $\mathrm{NaCl}$ plus $\mathrm{Zn}$ and $\mathrm{Cu}$ sulfates and oxides may be corrosion products covering those zones.

Therefore, it seems that zinc and copper sulfates predominate as corrosion products on the samples immersed in NSW, whereas those from immersions in ASW present copper and zinc sulfates and also copper and zinc chlorides. The identification of the crystalline corrosion products requires studies by other techniques, e.g., X-ray powder diffraction spectroscopy (Figure 8).

SEM images in Fig. 9 show that, after the removal of the corrosion products, samples from immersions in ASW show a cracked surface with white and black zones. The

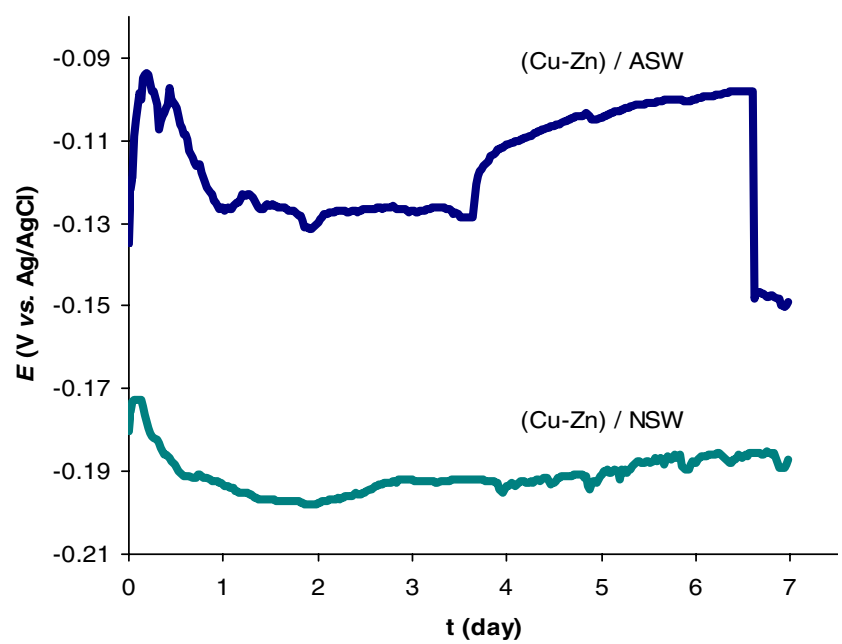

Fig. 7 Open-circuit potential curves of brass samples immersed during 1 week in nondeoxygenated buffered ASW (blue line) and NSW (green line)

black zones are rich in $\mathrm{Zn}, \mathrm{Cu}, \mathrm{S}$, and $\mathrm{Ca}$. Even after the removal of the corrosion products, some sulfates may remain on the surface. The cracked surface is certainly related with the dezincification process.

Furthermore, the morphology of the surface of samples immersed in NSW shows only black spots, indicating a superficial and uniform attack, most probably pits. This conclusion is in agreement with the conclusions from OCP data.

\section{Conclusions}

Cyclic voltammetric studies of brass in nonbuffered and buffered natural and artificial seawater, under anaerobic conditions, have allowed the following conclusions:

(1) Buffering the ASW contributes to a displacement of the anodic and the cathodic peaks to the positive direction, as well as to a significant decrease of the oxidation/reduction charges, whereas in NSW, this influence was not so well noticed, most probably due to the fact that NSW is already a buffered system.

(2) CVs of copper present much smaller anodic and cathodic charges than the corresponding ones of brass. The breakdown of passivity and the repassivation occur at

Table 5 Electrochemical parameters from the analysis of the polarization curves of brass

\begin{tabular}{|c|c|c|c|c|c|c|c|}
\hline \multirow[t]{2}{*}{ Medium } & \multicolumn{2}{|l|}{ LPR } & \multicolumn{5}{|c|}{ Tafel analysis } \\
\hline & $E_{\text {corr }}\left(\mathrm{V}\right.$ vs $\left.\mathrm{Ag}_{\mid}^{\prime} \mathrm{AgCl}\right)$ & $R_{\mathrm{p}}\left(\Omega \mathrm{cm}^{2}\right)$ & \multicolumn{2}{|c|}{$E_{\text {corr }}\left(\mathrm{V}\right.$ vs $\left.\mathrm{Ag}_{\mid} \mathrm{AgCl}\right)$} & \multicolumn{2}{|c|}{$j_{\text {corr }}\left(\mathrm{mA} \mathrm{cm}^{-2}\right)$} & $R_{\mathrm{p}}\left(\Omega \mathrm{cm}^{2}\right)$ \\
\hline NSW & -0.41 & 29 & -0.41 & 0.02 & 0.07 & $35 \times 10^{-5}$ & 40 \\
\hline ASW & -0.57 & 179 & -0.57 & 0.04 & 0.06 & $3.0 \times 10^{-5}$ & 223 \\
\hline
\end{tabular}


a
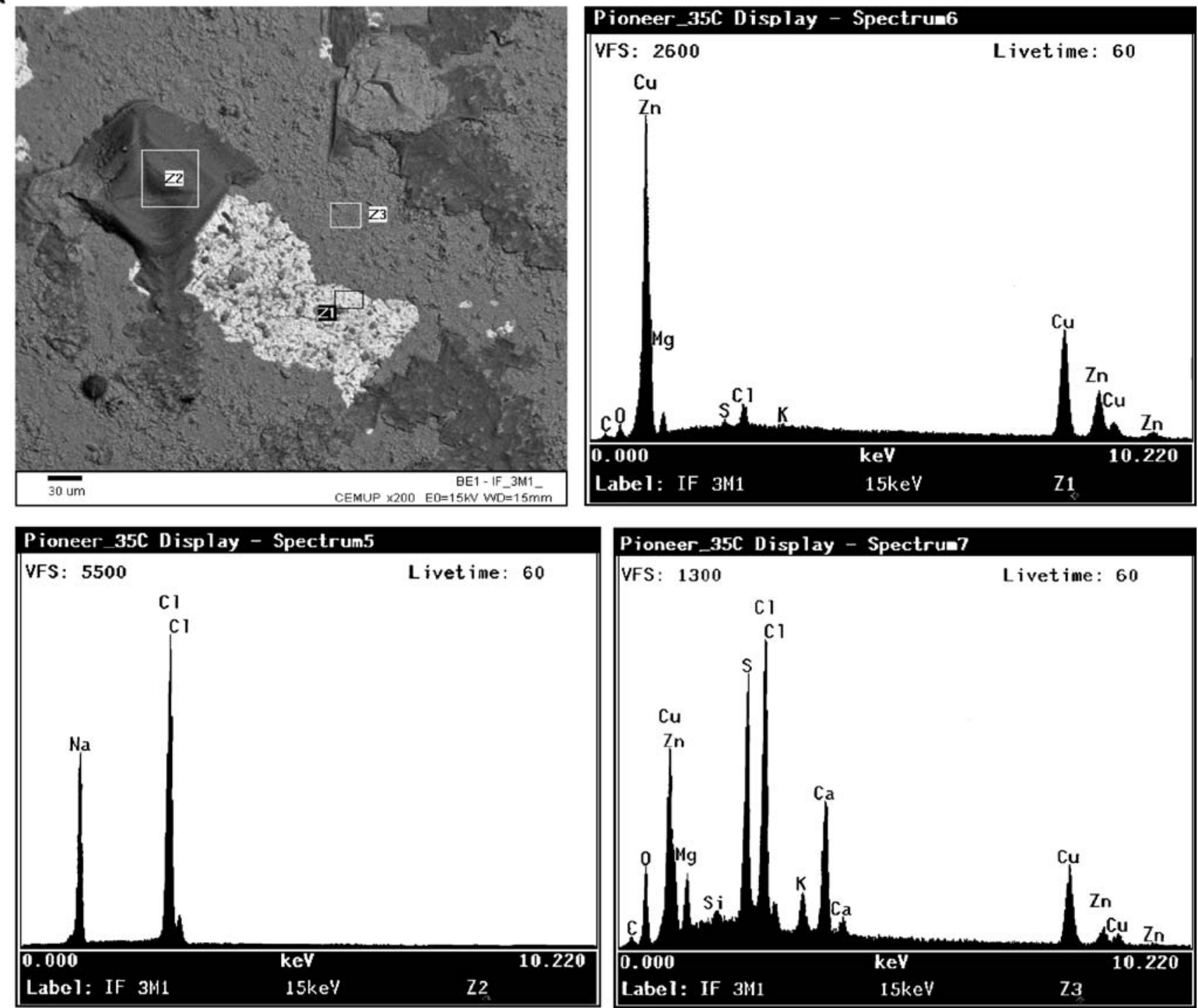

Fig. 8 SEM micrographs and EDS spectra of brass samples after 3 months of exposure in deoxygenated buffered seawater before the removal of corrosion products. a ASW. b NSW

much more anodic potentials on copper. In principle, the main differences observed between brass and copper can be attributed to the differences in the passive layer composition. The $\mathrm{ZnO} / \mathrm{Zn}(\mathrm{OH})_{2}+\mathrm{Cu} 2 \mathrm{O}+\mathrm{CuO} / \mathrm{Cu}(\mathrm{OH})_{2}$ structure of passivated brass is, probably, less resistant to chloride ion attack than the $\mathrm{Cu}_{2} \mathrm{O}+\mathrm{CuO} / \mathrm{Cu}(\mathrm{OH})_{2}$ layer formed on polycrystalline copper.

(3) The corrosion parameters, $E_{\text {corr }}, j_{\text {corr }}$, and $R_{\mathrm{p}}$, have demonstrated, in a quantitative way, the higher aggressivity of NSW.

(4) The open-circuit potential (OCP) measurements have shown much less noble potential for brass in NSW, followed by uniformly distributed oscillations, with small amplitude.

(5) The SEM micrographs of brass samples exposed to ASW and NSW show large and also small precipitates.
According to the corresponding EDS spectra, the larger precipitates are most probably crystals of $\mathrm{NaCl}$, which were observed on both samples, whereas the small precipitates present a composition dependent of the media. A white zone with a porous nature is observed on samples immersed in ASW, probably related with dealloying "dezincification". After the removal of the corrosion products, the morphology of the surfaces corresponding to immersions in ASW presents a uniformly cracked surface along the boundaries, whereas those from immersions in NSW show pits uniformly distributed along the whole surface.

Studies on the corrosion product identification are under progress in our research group. 
b
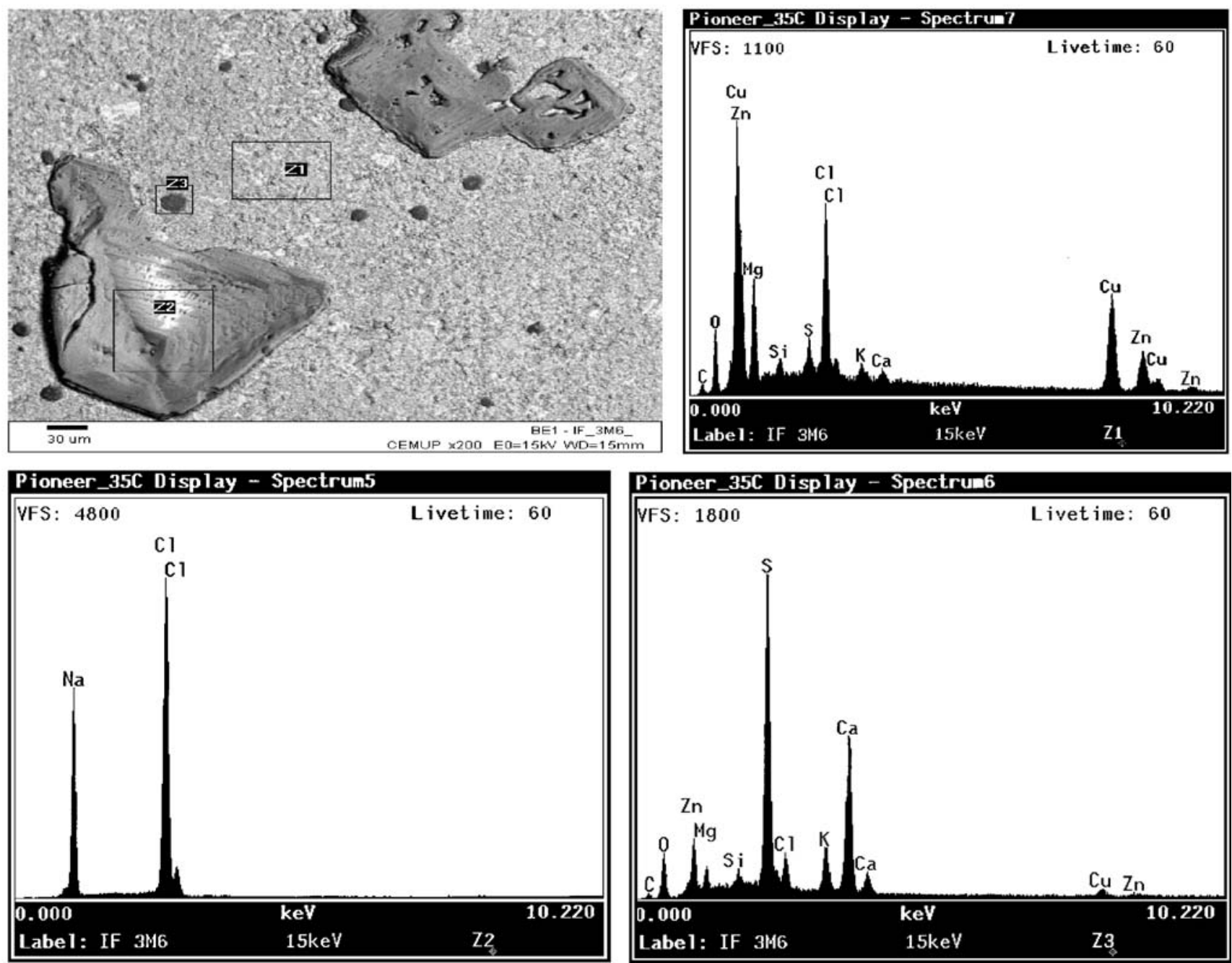

Fig. 8 (continued)

Fig. 9 SEM micrographs of brass samples with 3 months of exposure in deoxygenated buffered seawater after the removal of the corrosion products. a ASW. b NSW

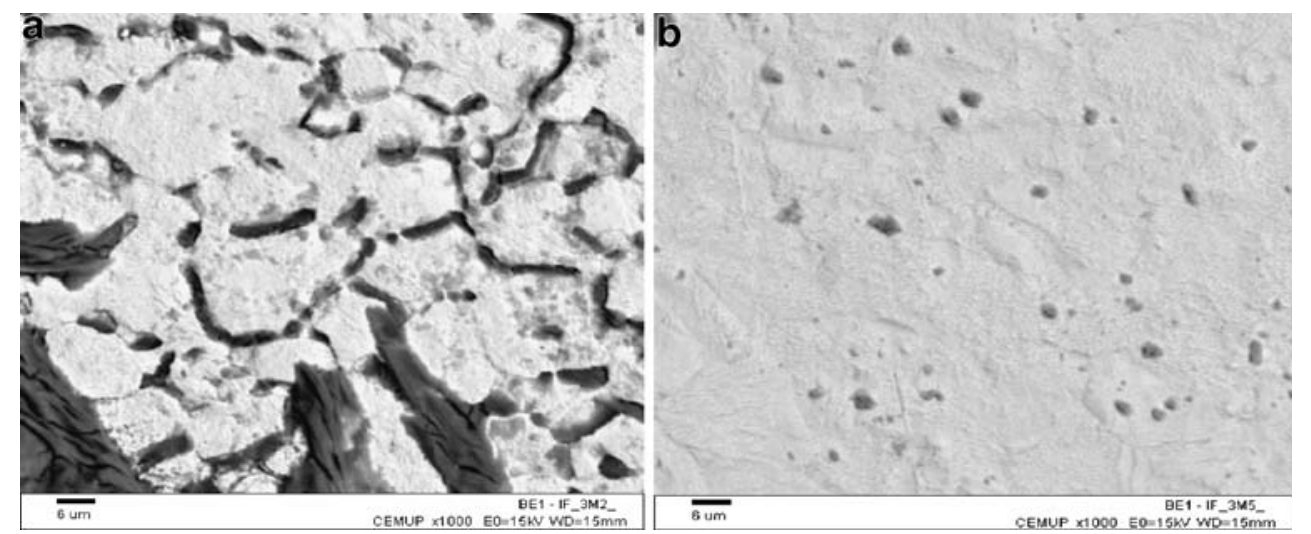


Acknowledgment Financial support from the Portuguese Foundation for Science and Technology (FCT) is acknowledged.

\section{References}

1. Quartanone MA, Moretti G, Bellani T (1998) Corrosion 54:606

2. Elmorsi MA, El-Sheikh MY, Bastweesy AM, Ghoneim MM (1991) Bull Electrochem 71:58

3. Sugawara H, Ebiko H (1967) Corros Sci 7:513

4. Dinnappa R, Mayanna SM (1987) Corros Sci 27:349

5. Polunin AV, Pchelnikov AP, Losev VV, Marshakov IK (1982) Electrochim Acta 27:467

6. Chialvo MR, Salvarezza RC, Vasquez Moll D, Arvia A (1985) Electrochim Acta 30:1501

7. Gad-Allah AG, Abou-Ronia MM, Badway MW, Reha HH (1991) J Appl Electrochem 21:829

8. Morales J, Fernandez GT, Esparza P, Gonzalez S, Salvarezza RC, Arvia AJ (1995) Corros Sci 37:211

9. Morales J, Fernandez GT, Gonzalez S, Esparza P, Salvarezza RC, Arvia AJ (1998) Corros Sci 40:177

10. Biton MG, Aurbach D, Mishkov P, Ilzycer D (2006) J Electrochem Soc 153:B555

11. Kabasakaloglu M, Kryak T, Sendil O, Asan A (2002) Appl Surf Sci 193:167

12. El-Sherif RM, Ismail KM, Badawy WA (2004) Electrochim Acta 49:5139

13. Rudd A, Breslin CB (2000) Electrochim Acta 45:4015

14. Badawy WA, El-Egamy SS, El-Azab SS (1995) Corros Sci 37:1969
15. Rylkina MV, Kuznetsov Yu I, Kalashnikova MV, Eremina MA (2002) Prot Met 38:340

16. Kosec T, Milošev MI, Pihlar B (2005) J Appl Electrochem 35:975

17. Milošev I, Mikić KT, Gaberšček M (2006) Electrochim Acta 5:415

18. Milošev I, Strehblow H-H (2003) J Electrochem Soc 150:B517

19. Morales J, Esparza P, Fernandez GT, Gonzalez S, Gracia JE, Caceres J, Salvarezza RC, Arvia AJ (1995) Corros Sci 37:231

20. Darou K, Bellakhal N, Cheron BG, Brisset JL (1998) Mater Res Bull 33:1117

21. Mansfeld F, Little B (1992) Corros Sci 37:1992

22. Habib K, Riad W, Muhanna K, Al-Sumait H (2002) Desalination $142: 5$

23. Ravichandra R, Rajendran N (2005) Appl Surf Sci 241:449

24. Santos CIS (2005) Corrosion of brass. Master thesis, University of Lisboa, Lisboa

25. Santos CIS, Mendonça MH, Fonseca ITE (2006) J Appl Electrochem 36:1311

26. Hostis L, Gagbert C, Féron D (2003) Electrochim Acta 48:1451

27. Ferreira JP, Rodrigues JA, Fonseca ITE (2004) J Solid State Electrochem 8:260

28. Sinapi F, Deroubaix S, Pirlot C, Delhalle J, Mekhalif Z (2004) Electrochim Acta 49:2987

29. Sinapi F, Forget L, Delhalle J, Mekhalif Z (2002) Surf Interface Anal 34:148

30. Mountassir Z, Srhiri A (2007) Corros Sci 49:1350

31. Rand MC, Arnold WFC, Greenberg EG, Taras MJ (1975) Standards methods for the examination of water and wastewater, 4th edn. American Public Health Association. Washington, DC

32. Mansfeld F, Hsu CH, Sun Z, Örnek D, Wood TK (2002) Corrosion 58:187 